\title{
Cyclic AMP Inhibits Secretion From Electroporated Human Neutrophils
}

\author{
James E. Smolen, Sally J. Stoehr, and Barbara Kuczynski \\ Departments of Pediatric Hematology/Oncology (J.E.S., S.J.S., B.K.) and Pathology (J.E.S.), University of Michigan Medical Center, \\ Ann Arbor
}

\begin{abstract}
It has long been known that intracellular CAMP inhibits and CGMP enhances intact neutrophil function. However, these effects are modest and require relatively high concentrations of the cyclic nucleotides. We decided to re-examine the effects of cyclic nucleotides on $\mathrm{Ca}^{2+}$-induced secretion by electroporated cells. This system allowed us to bypass normal cell surface receptor-ligand interactions as well as to directly expose the intracellular space to native cyclic nucleotides. We found that concentrations of CAMP as low as $3 \mu \mathrm{M}$ inhibited $\mathrm{Ca}^{2+}$-induced secretion; 30-300 $\mu$ M cAMP was maximally inhibitory. cAMP was actually slightly more potent than dibutyryl cAMP, a membrane-permeant derivative. In contrast, cGMP was only slightly stimulatory at $3 \mu \mathrm{M}$ and modestly inhibltory at $300 \mu \mathrm{M}$; dibutyryl cGMP was ineffective. A more detailed investigation of the effects of CAMP showed that inhibition was only obtained in the presence of $\mathrm{Mg}^{2+}$. Half-maximal inhibition by CAMP occurred at 10-30 $\mu$ M. Inhibition by CAMP was achieved by shifting the $\mathrm{Ca}^{2+}$ dose-response curve for secretion to the right; this was observed for the release of both specific granules (vitamin $B_{12}$ binding protein) and azurophil granules (B-glucuronidase). We previously showed that ATP could enhance $\mathrm{Ca}^{2+}$-induced secretion in the presence of $\mathrm{Mg}^{2+}$, apparently by interacting with a cell surface purine receptor. However, increasing concentrations of ATP could not overcome inhibition by CAMP; this suggested that CAMP acted at some site other than the purine receptor. Inhibition by CAMP was also less apparent in the presence of the protein kinase $\mathbf{C}$ agonist phorbol myristate acetate (PMA), suggesting that the cyclic nucleotide did not produce systemic desensitization of the neutrophils. In summary, these results demonstrate that low, physiologically relevant concentrations of CAMP can modulate neutrophil responsiveness.
\end{abstract}

Key words: degranulation, cyclic nucleotides, granulocytes

\section{INTRODUCTION}

We and others have used a variety of means to render neutrophil plasma membranes permeable for the purposes of studying intracellular signal transduction. Neutrophils permeabilized with saponin and digitonin can be induced to degranulate by exposure to $\mathrm{Ca}^{2+}$ alone $[34,42,43]$. Secretion from both specific and azurophil granule can be elicited by $\mathrm{Ca}^{2+}$, with specific granules being the more sensitive. A different method of permeabilizing neutrophils was pioneered by Grinstein and Furuya [10], who used high voltage electric fields to render human neutrophils permeable to molecules of $\mathrm{M}_{\mathrm{r}}<700 \mathrm{Da}$. These investigators were thereby able to introduce Ca-EGTA buffers and NADPH into the cytosol and to stimulate $\mathrm{O}_{2}$ consumption by these cells following exposure to surface stimuli; all experiments were done in the presence of Mg-ATP. More recently, Nasmith et al. [31] reported that a non-hydrolyzable guanine nucleotide, GTP- $\gamma-S$, induces both $\mathrm{O}_{2}$ consumption and tyrosine phosphorylation on its own. Activation of the respiratory burst requires the presence of $\mathrm{Mg}^{2+}$ and
ATP. Our own work showed that electroporated neutrophils secrete granule contents in response to increases in $\mathrm{Ca}^{2+}$ alone [41]. This degranulation is enhanced by $\mathrm{Mg}^{2+}$ and a wide variety of hydrolyzable and stable nucleotide phosphates in the presence of $\mathrm{Mg}^{2+}$. The nucleotides appear to be interacting with a non-specific purine receptor which is coupled to protein kinase $\mathbf{C}$.

Permeabilization also permits direct access of cyclic nucleotides to the cytoplasmic space. These compounds play a second messenger role in some cell types. Indeed, exposure of neutrophils to phagocytizable particles results in a rapid (maximal within $15 \mathrm{sec}$ ) and brief (returning to basal levels in 1-2 min) doubling of cyclic adenosine 3',5'-monophosphate (cAMP) levels [12]. Stimulated increments in cAMP levels were later re-

Received March 12, 1990; accepted June 27, 1990.

Reprint requests: James E. Smolen, University of Michigan, Department of Pediatrics, Room 7510C MSRB I, Box 0684, Ann Arbor, MI 48109-0684. 
ported in rabbit [21] and human $[11,13,28,30,36,40]$ neutrophils. The observations that changes in cAMP levels correlate closely with chemotaxis and degranulation [30], display specific desensitization after repeated exposures to the same stimulus, and that this desensitization is accompanied by a parallel decrease in superoxide $\left(\mathrm{O}_{2}^{-}\right)$generation [35] suggest that changes in cyclic nucleotide levels may be of mechanistic significance. However, these observations are only correlative and a number of lines of evidence suggest that changes in cAMP are not important in stimulus-response coupling in neutrophils. First, cAMP increases can be induced by low concentrations of FMLP, without accompanying degranulation or $\mathrm{O}_{2}^{-}$generation [40], suggesting that the former events are not sufficient for the latter. Second, increments in CAMP do not appear to be necessary for discharge of specific granules or $\mathrm{O}_{2}^{-}$generation $[30,44]$. Finally, an inhibitor of adenylate cyclase, which blocks the stimulated increase in cAMP, does not impair neutrophil responses [37]. These findings seem to rule out cAMP in a second messenger role.

In spite of our previous report that cyclic nucleotides have no effect upon secretion from saponin- or digitoninpermeabilized neutrophils $[42,43]$ and the evidence cited above militating against a role for these compounds in stimulus-response coupling, a number of factors persuaded us to re-examine the issue. The first was the development of an electroporation system for permeabilizing neutrophils, which proved to have substantially different properties from those obtained using cholesterol-complexing agents [41]; this is likely related to the sizes of the pores induced by the different techniques. The second factor was a renewed interest in this area of investigation: increments in cAMP have been linked to calmodulin-dependent processes [20], the effects of cyclic nucleotides have been shown to be dependent upon the stimulus employed [29,32,52], and cAMP has been shown to affect the functions of other permeabilized cell types $[4,22,47-49]$. In the studies reported here, we found that micromolar concentrations of cAMP inhibited $\mathrm{Ca}^{2+}$-induced secretion from electropermeabilized human neutrophils. This inhibition required $\mathrm{Mg}^{2+}$ and resulted from a shift in the $\mathrm{Ca}^{2+}$ dose-response curve to the right.

\section{MATERIALS AND METHODS Reagents}

cAMP, cGMP, dibutyryl cAMP, dibutyryl cGMP, ATP (adenosine 5'-triphosphate), and phorbol myristate acetate (PMA) were purchased from Sigma Chemical Company (St. Louis, MO). [ $\left.\gamma-{ }^{32} \mathrm{P}\right]-\mathrm{ATP}$ was obtained from Amersham (Arlington Heights, IL). K-252a was purchased from Kamiya Biomedical Co. (Thousand
Oaks, CA). All chemicals for SDS-PAGE were electrophoresis grade, and all other materials were reagent grade.

\section{Preparation of Cell Suspensions}

Heparinized (10 units/ml) venous blood was obtained from healthy adult donors. Purified preparations of neutrophils were isolated from this blood by means of Hypaque/Ficoll gradients [6] followed by standard techniques of dextran sedimentation and hypotonic lysis of erythrocytes [53]. This allowed studies of cell suspensions containing $98 \pm 2 \%$ neutrophils with few contaminating platelets or erythrocytes. The cells were washed and finally suspended in a buffer consisting of $138 \mathrm{mM}$ $\mathrm{NaCl}, 2.7 \mathrm{mM} \mathrm{KCl}, 8.1 \mathrm{mM} \mathrm{Na} \mathrm{HPO}_{4}, 1.5 \mathrm{mM}$ $\mathrm{KH}_{2} \mathrm{PO}_{4}$. For permeabilization studies, the cells were instead washed once and resuspended in $\mathrm{KCl}$-HEPES buffer $(100 \mathrm{mM} \mathrm{KCl}, 20 \mathrm{mM} \mathrm{NaCl}, 1 \mathrm{mM}$ EGTA, and $30 \mathrm{mM}$ HEPES, $\mathrm{pH}$ 7.0).

\section{Neutrophil Permeabilization}

Electropermeabilization was conducted essentially as described by Grinstein and Furuya [10] with some variations [41]. In essence, neutrophils were washed and then resuspended in ice-cold KCl-HEPES buffer; $\mathbf{M g}$ ATP and $\mathrm{Ca}^{2+}$ were not included at this time. The cells, at a concentration of $5 \times 10^{7}$ per $\mathrm{ml}$, were transferred to a chilled Biorad Pulsar cuvette and subjected to three discharges of $5 \mathrm{kV} / \mathrm{cm}$ from a $25 \mu \mathrm{F}$ capacitor (Biorad Gene Pulsar) with gentle stirring between each pulse. The capacitor discharged with a time constant of $0.5-0.7 \mathrm{~ms}$ under these conditions. All permeabilization operations were conducted at $4^{\circ} \mathrm{C}$. Viability, as assessed by trypan blue exclusion, was consistently greater than $85 \%$, in accord with Grinstein and Furuya [10].

\section{Lysosomal Enzyme Release}

Following permeabilization, neutrophils were used with or without washing, as indicated. Aliquots of the ice-cold permeabilized cell suspensions $(100 \mu l$, containing $5 \times 10^{6}$ cells) were added to $900 \mu$ l of pre-warmed $\mathrm{KCl}$-HEPES buffer containing the indicated additions along with the desired concentration of free $\mathrm{Ca}^{2+}$ (determined for the buffer using a $\mathrm{Ca}^{2+}$ electrode [5]). The cells were then incubated at $37^{\circ} \mathrm{C}$ for $7 \mathrm{~min}$; cells incubated without $\mathrm{Ca}^{2+}$ and intact neutrophils (in $\mathrm{KCl}$-HEPES buffer) were employed as routine controls. The cell suspensions were then centrifuged at $750 \mathrm{~g}$ for 10 min. Aliquots of the supernatants were taken for standard determinations of $\beta$-glucuronidase [7] (an enzyme found exclusively in azurophil granules), lysozyme [1] (an enzyme found in both specific and azurophil granules), and vitamin $B_{12}$ binding protein [38] (a component of specific granules alone). 


\section{Electrophoresis and Autoradiography}

Trichloroacetic acid precipitates from incubates with $\left[\gamma-{ }^{32} \mathrm{P}\right]-\mathrm{ATP}$ and appropriate cofactors [45] were extracted in acetone, dried, and resuspended in sample buffer $(12.5 \%$ glycerol, $5 \% \quad \beta$-mercaptoethanol, $2 \%$ SDS, $62 \mathrm{mM}$ Tris, $\mathrm{pH} 6.8$, and $0.005 \%$ bromophenol blue). The samples were sonicated and heated at $100^{\circ} \mathrm{C}$ for $5 \mathrm{~min}$ before loading onto gels.

Electrophoresis was conducted using 10 or $12 \%$ minislab gels $(0.5 \times 55 \times 85 \mathrm{~mm})$ or 10,12 , or $15 \%$ slab gels $(0.75 \mathrm{~mm} \times 16 \mathrm{~cm} \times 18 \mathrm{~cm})$ and the discontinuous buffer system of Laemmli [27]. Samples were loaded on the mini-slab gels at approximately $5 \times 10^{5}$ cell equivalents per lane and were electrophoresed at a constant voltage of $180 \mathrm{~V}$ for $1 \mathrm{~h}$ at $4^{\circ} \mathrm{C}$. Samples were loaded at a concentration of $2 \times 10^{6}$ cell equivalents per lane on $16 \times 18 \mathrm{~cm}$ gels and electrophoresis was conducted at a constant current of $15 \mathrm{~mA}$ for $3 \mathrm{~h}$ at room temperature. All gels were stained with Coomassie Brilliant Blue. Mini-gels were air dried between cellophane membrane backing (BioRad), while $16 \times 18 \mathrm{~cm}$ gels were dried between cellophane membranes under vacuum at $80^{\circ} \mathrm{C}$ on a Biorad gel dryer. For autoradiographic analysis, gels were exposed to X-Omat XAR-5 film at $-70^{\circ} \mathrm{C}$ for $1-10$ days, with or without enlightening plus intensifying screens.

\section{RESULTS}

We have previously shown that electroporated neutrophils can be induced to secrete lysosomal constituents in response to micromolar levels of free $\mathrm{Ca}^{2+}$ [41]. This secretion is enhanced by $\mathrm{Mg}^{2+}$ and several nucleotides (in the presence of $\mathrm{Mg}^{2+}$ ). In the course of these studies, we found that micromolar concentrations of cAMP could inhibit degranulation in this system. Figure 1 demonstrates both the properties of $\mathrm{Ca}^{2+}$-induced secretion and inhibition by cAMP. In the presence of $\mathrm{Mg}^{2+}$ alone (control), low concentrations of $\mathrm{Ca}^{2+}$ evoked secretion from specific granules, as indicated by the release of vitamin $B_{12}$ binding protein (upper left panel, open circles). When $30 \mu \mathrm{M}$ cAMP was also present, degranulation was inhibited over the entire range of $\mathrm{Ca}^{2+}$ (squares; solid symbols indicate statistical significance from corresponding control points). In the additional presence of ATP, control release of vitamin $B_{12}$ binding

Vitamin B12 Binding Protein
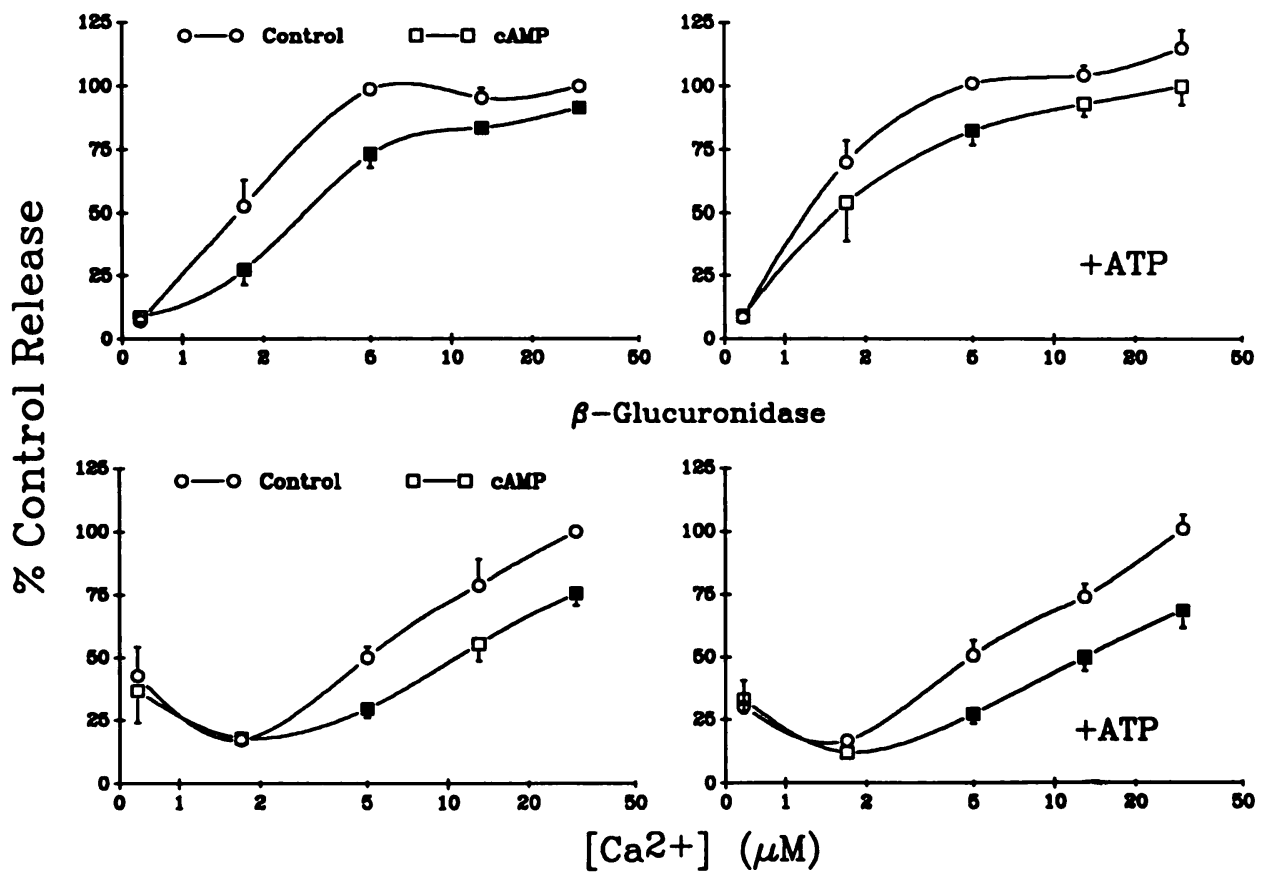

Fig. 1. Effects of ATP and CAMP on $\mathrm{Ca}^{2+}$-induced secretion from electroporated human neutrophils. Human neutrophils were permeabilized as detailed in "Materials and Methods" and stimulated with the indicated concentrations of free $\mathrm{Ca}^{2+}$ in the presence of $\mathrm{Mg}^{2+}(1 \mathrm{mM})$. Where relevant, the incubations also included CAMP ( $30 \mu \mathrm{M}$; square symbols) and ATP $(300 \mu \mathrm{M})$. The reaction mixtures were incubated for 7 minutes at $37^{\circ} \mathrm{C}$ and then centrifuged. Release of vitamin $\mathrm{B}_{\mathbf{1 2}}$ binding protein (top) and B-glucuronidase (bottom) were measured in supernatant fluids.
The results are given as a percentage of control release, namely that elicited by $30 \mu \mathrm{M} \mathrm{Ca}{ }^{2+}$ in the absence of CAMP; these control release values were $49.9 \pm 17.2 \%$ of total cellular vitamin $B_{12}$ binding protein and $20.0 \pm 4.0 \%$ B-glucuronidase. The results shown are the means \pm s.e.m. for four experiments. Solid symbols denote those data points which were significantly different $(P<.05$, paired Student t-test) from the absence of added CAMP. 
protein was slightly increased; inhibition by cAMP was still observed but was only statistically significant at 5 $\mu \mathrm{M} \mathrm{Ca}^{2+}$. A similar pattern was seen with secretion from azurophil granules, as measured by B-glucuronidase (lower panels), except that substantially more $\mathrm{Ca}^{2+}$ was required [41]. cAMP inhibited secretion from this granule type over most of the $\mathrm{Ca}^{2+}$ dose range. The clearest overall pattern was for vitamin $B_{12}$ binding protein (upper left panel), which encompassed a full dose-response curve. In this case, the most pronounced effect of cAMP was in the middle ranges, as the nucleotide appeared to shift the $\mathrm{Ca}^{2+}$ dose-response curve to the right.

We wished to see whether inhibition by cAMP was unique to this nucleotide and whether permeant analogues of the cyclic nucleotides had any greater effect. For these experiments, we selected optimal conditions for detection of inhibition of vitamin $B_{12}$ binding protein release by cAMP: i.e., a mid-range $\mathrm{Ca}^{2+}$ concentration $(5 \mu \mathrm{M})$ in the presence of the full secretory system $\left(\mathrm{Mg}^{2+}\right.$ plus ATP). As shown in Figure 2, cAMP inhibited secretion at concentrations as low as $3 \mu \mathrm{M}$ (left set of bars), with greater effect at 30 and $300 \mu \mathrm{M}$. Dibutyryl cAMP (dbcAMP), a membrane-permeant derivative, was slightly less potent than cAMP itself; this is not unexpected since native cAMP should readily penetrate permeabilized cells and the larger dibutyryl derivative might traverse the pores even more slowly. cGMP activated degranulation only slightly at $3 \mu \mathrm{M}$; at high concentrations, this nucleotide was actually inhibitory. The dibutyryl derivative of cGMP had essentially no effect, with marginal but statistically significant inhibition at $30 \mu \mathrm{M}$ only.

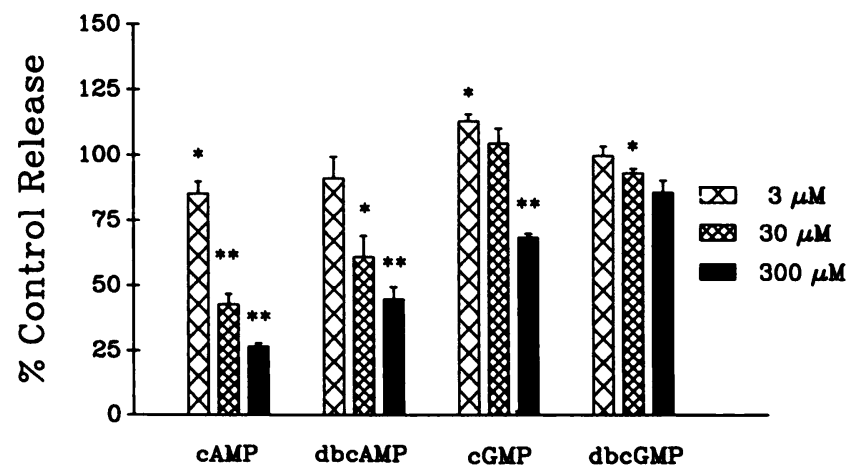

Fig. 2. Effects of various cyclic nucleotides on secretion of vitamin $\mathbf{B}_{\mathbf{1 2}}$ binding protein. Permeabilized neutrophils were incubated with $\mathrm{Ca}^{2+}(5 \mu \mathrm{M}), \mathrm{Mg}^{2+}(1 \mathrm{mM})$, and ATP $(300 \mu \mathrm{M})$ in the presence of $0,3,30$, or $300 \mu M$ CAMP, dibutyryl CAMP (dbcAMP), cyclic GMP (cGMP), or dibutyryl cGMP (dbcGMP), as indicated. Vitamin $B_{12}$ binding protein was assayed and release is expressed as a percentage of that obtained with control cells (absence of any nucleotide); this control value represented $21.2 \pm 7.1 \%$ of the total cellular content (three experiments). Asterisks indicate the level of significant differences from control values ( ${ }^{*} P<.05 ;{ }^{* \star} P<.01$, paired Student t-test).
In an effort to get a more detailed description of inhibition induced by cAMP, we varied the concentration of the cyclic nucleotide in the presence and absence of $\mathrm{Mg}^{2+}$ and ATP, at a fixed (5 $\left.\mu \mathrm{M}\right) \mathrm{Ca}^{2+}$ concentration. Figure 3 (upper panel) shows that in the absence of $\mathrm{Mg}^{2+}$ or ATP (circles), cAMP had no effect. In the presence of ATP alone (triangles), cAMP was only slightly inhibitory. The lower panel shows that $\mathrm{Mg}^{2+}$ (squares) was required for inhibition by cAMP at 30 and $100 \mu \mathrm{M}$. When ATP was present along with $\mathrm{Mg}^{2+}$ (diamonds), significant inhibition by cAMP was seen from 10 to $100 \mu \mathrm{M}$.

One possible model for our findings was that cAMP, in the presence of $\mathrm{Mg}^{2+}$, was inhibiting the potentiation by $\mathrm{Mg}^{2+}$ of $\mathrm{Ca}^{2+}$-induced secretion. We therefore wished to see if cAMP simply reversed the $\mathrm{Mg}^{2+}$. enhancement of secretion and returned it to the level obtained with $\mathrm{Ca}^{2+}$ alone. In experiments not shown, we found that degranulation in the presence of cAMP and $\mathrm{Mg}^{2+}$ could be reduced below that obtained with $\mathrm{Ca}^{2+}$ alone. Thus, the data were not in accord with the

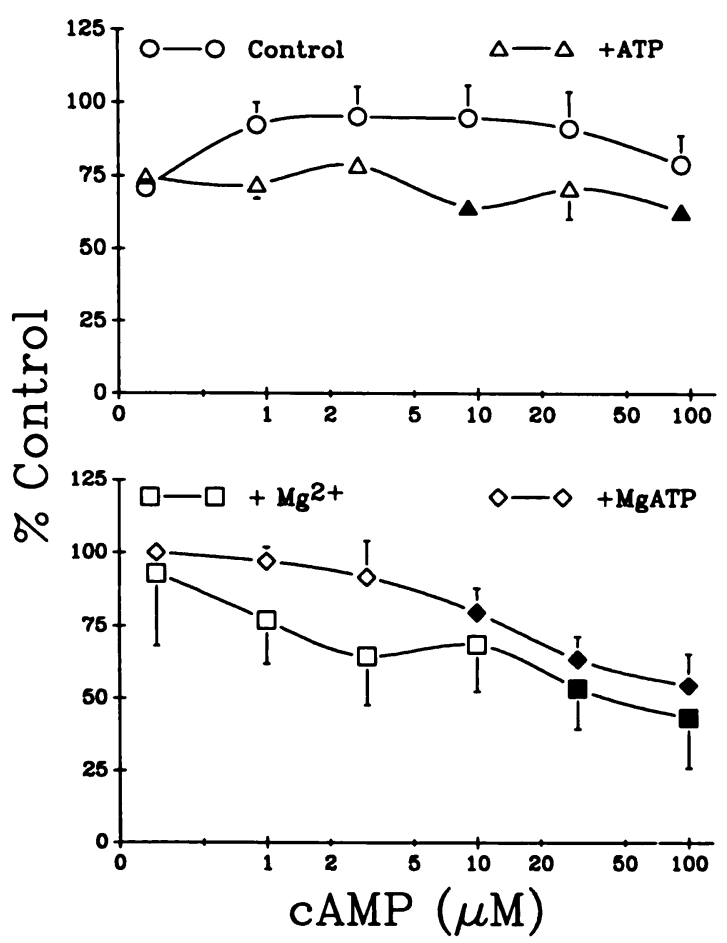

Fig. 3. Effects of various CAMP concentrations on secrotion in the presence and absence of $\mathrm{Mg}^{2+}$ and ATP. Permeabilized neutrophils were incubated with $\mathrm{Ca}^{2+}(5 \mu \mathrm{M})$ and the indicated concentration of CAMP, with or without $\mathrm{Mg}^{2+}(1 \mathrm{mM})$ or ATP (300 $\mu M)$. Vitamin $B_{12}$ binding protein was assayed and release is expressed as a percentage of that obtained with control cells (absence of CAMP, presence of Mg-ATP); this control value represented $29.2 \pm 12.2 \%$ of the total cellular content (four experiments). Solid symbols denote those data points which were significantly different $(P<.05$, paired Student t-test) from the absence of added CAMP. 


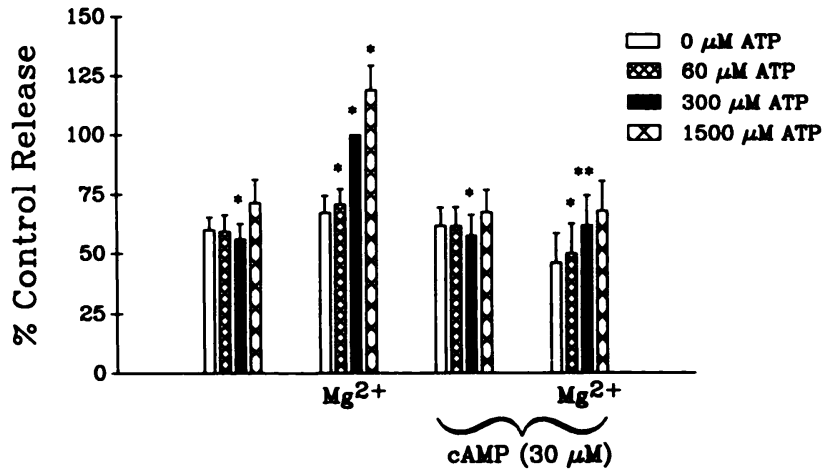

Fig. 4. Effect of ATP on inhibition by cAMP. Permeabilized neutrophils were incubated with $\mathrm{Ca}^{2+}(5 \mu \mathrm{M})$ and $30 \mu \mathrm{M}$ CAMP, with or without $\mathrm{Mg}^{2+}(1 \mathrm{mM})$ or the indicated concentrations of ATP. Vitamin $B_{12}$ binding protein was assayed and release is expressed as a percentage of that obtained with control cells (absence of CAMP, presence of $300 \mu \mathrm{M} \mathrm{Mg-ATP);} \mathrm{this} \mathrm{control}$ value represented $\mathbf{4 0 . 9} \pm \mathbf{7 . 0 \%}$ of the total cellular content (three experiments). Asterisks indicate the level of significant differences from equivalent samples without ATP ( ${ }^{* P}<.05 ;{ }^{* * P}<.01$, paired Student t-test).

model cited above and cAMP thus was not simply an antagonist for the action of $\mathrm{Mg}^{2+}$. In other control experiments, we found that neither the phosphodiesterase inhibitor theophylline nor the adenylate cyclase activator $\mathrm{PGE}_{1}$ potentiated the action of CAMP (not shown). This would be expected since in permeabilized, but not intact, cells the cAMP level would be "clamped" by the concentration present in the medium.

Because ATP appears to stimulate $\mathrm{Ca}^{2+}$-induced secretion by interacting with a non-specific purine nucleotide binding site [41], we wished to determine whether cAMP also interacted with the same receptor. Unfortunately, no specific inhibitor of this receptor has been reported. Consequently, the most direct experiments we could perform were to see if ATP itself could compete with cAMP and overcome its inhibition. As shown in Figure 4 , increasing concentrations of ATP from 0 to $1,500 \mathrm{M}$ produced little change in $\mathrm{Ca}^{2+}$-induced secretion in the absence of $\mathrm{Mg}^{2+}$ (left set of bars). When $\mathrm{Mg}^{2+}$ was present (second set of bars), increasing concentrations of ATP produced greater degranulation. As shown before, cAMP had no effect in the absence of $\mathrm{Mg}^{2+}$ (third set); however, in the presence of this divalent cation (fourth set of bars), cAMP did inhibit ATPenhanced secretion, even in the presence of $1,500 \mu \mathrm{M}$ nucleotide. The fact that high concentrations of ATP did not counteract inhibition by cAMP indicated that the cyclic nucleotide was interacting at a site other than that utilized by ATP (presumably the purine receptor).

In order to see whether cAMP produced a systemic desensitization of neutrophil secretion, we examined the effects of this nucleotide on cells in which protein kinase
Vitamin B12 Binding Protein

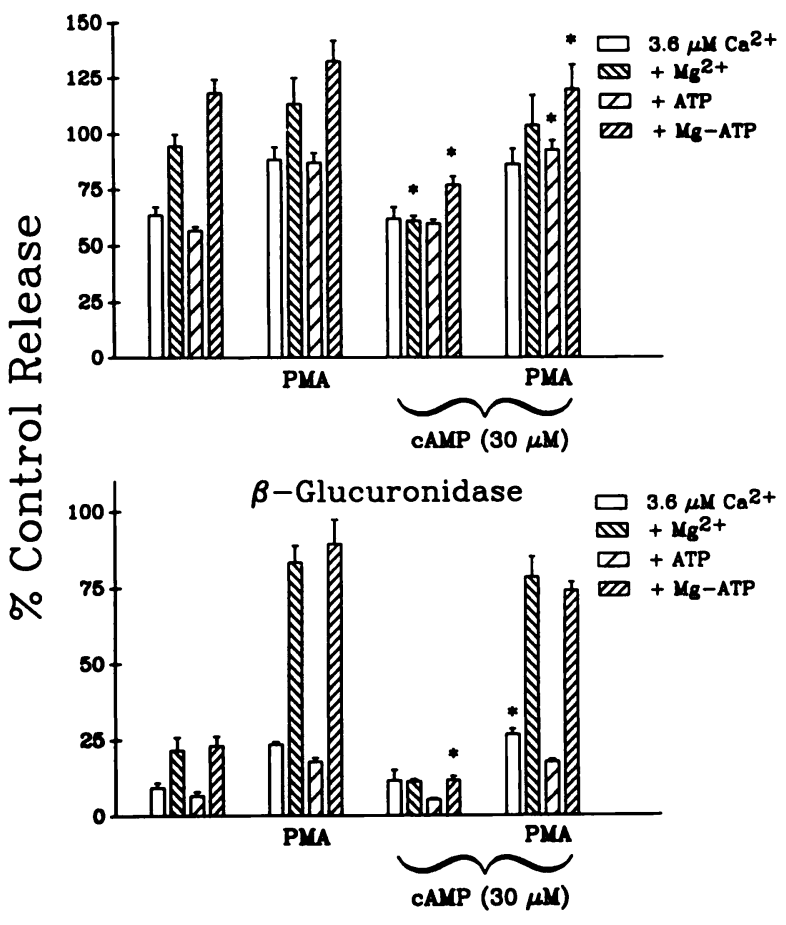

Fig. 5. Effect of PMA on inhibition by CAMP. Permeabilized neutrophils were incubated with $\mathrm{Ca}^{2+}(3.6 \mu \mathrm{M})$ and with or without CAMP $(30 \mu \mathrm{M}), \mathrm{Mg}^{2+}(1 \mathrm{mM})$, ATP $(300 \mu \mathrm{M})$, or PMA (10 $\mathrm{ng} / \mathrm{ml})$, as indicated. Vitamin $B_{12}$ binding protein and B-glucuronidase were assayed and release is expressed as a percentage of that obtained with control cells (absence of CAMP, presence of PMA and $60 \mu \mathrm{M} \mathrm{Ca}{ }^{2+}$ ); this control value represented $34.1 \pm 1.4 \%$ of the total cellular content of vitamin $B_{12}$ binding protein and $16.6 \pm 1.7 \%$ of the total B-glucuronidase (three experiments). Asterisks indicate samples which were significantly different in the presence of CAMP $(P<.05$, paired Student t-test).

C (PKC) was stimulated by phorbol myristate acetate (PMA). We have previously shown that PMA synergistically enhances $\mathrm{Ca}^{2+}$-induced secretion from electroporated neutrophils in the presence of $\mathrm{Mg}^{2+}$ and $\mathrm{Mg}^{2+}$. ATP [41]; in this report, we showed that PMA reduces the $\mathrm{Ca}^{2+}$ requirement for half-maximal specific granule secretion from 3 to $0.5 \mu \mathrm{M}$. The upper panel of Figure 5 shows $\mathrm{Ca}^{2+}$-induced release of vitamin $\mathrm{B}_{12}$ binding protein; the left set of bars presents control data. It can be seen that $\mathrm{Mg}^{2+}$ and $\mathrm{Mg}^{2+}$-ATP (but not ATP alone) increased degranulation stimulated by $\mathrm{Ca}^{2+}$, as expected. This pattern was enhanced in the presence of PMA (second set of bars). When cAMP (and $\mathrm{Mg}^{2+}$ ) was present, release of vitamin $B_{12}$ binding protein was strongly inhibited (compare the first and third sets of bars). However, when PMA was also present, inhibition by cAMP was much muted (compare second and fourth set of bars). A similar pattern was also seen for the release of B-glucuronidase (lower panel). 
The most likely means by which cAMP inhibited degranulation was by stimulating a cAMP-dependent protein kinase (PKA). We were unable to overcome cAMP inhibition using $\mathrm{K}-252 \mathrm{a}$, an inhibitor of this kinase (data not shown). This is probably because $\mathrm{K}-252$ a could also inhibit protein kinase $\mathrm{C}$, which is required for ATP-enhanced secretion [41]. We also attempted to determine the molecular target of the putative PKA. Neutrophils were electroporated in the presence of $[\gamma$ $\left.{ }^{32} \mathrm{P}\right]$-ATP, either carrier-free or with $30 \mu \mathrm{M}$ unlabeled ATP, and then exposed to $\mathrm{Ca}^{2+}, \mathrm{Mg}^{2+}$, and cAMP under conditions which inhibited secretion. Phosphorylated proteins were analyzed by SDS-PAGE followed by autoradiography. In essence, we were unable to find any proteins which were specifically phosphorylated in the presence of cAMP, with or without the divalent cations (not shown).

\section{DISCUSSION}

It has long been known that agents which increase intracellular cAMP levels reduce neutrophil responsiveness while those agents which increase cGMP concentrations enhance cellular functions [54]. The potential importance of these second messengers is amplified by the prompt production of cAMP following neutrophil stimulation $[12,36,40]$ and correlation of these increments with azurophil granule secretion [44]. While stimulus-elicited increases in cGMP have been reported [17-19], they have not been observed at early times by others $[36,40]$.

One of the difficulties in cyclic nucleotide research is that the effects of these agents on neutrophil function are quite modest. High concentrations of dibutyryl cAMP $(>150 \mu \mathrm{M})$ are often needed to obtain $20 \%$ inhibition of degranulation and the putative stimulation obtained with dibutyryl cGMP is often not evident [39]. Compounding this problem is the fact that the effects of cyclic nucleotides are dependent upon both the stimulus [20,29, $32,51,52]$ and the response $[9,26]$ being examined. An additional difficulty with most studies is that intracellular cyclic nucleotide levels must be modulated either directly by adding membrane-permeant derivatives or indirectly by use of prostaglandins or beta-adrenergic agents. However, with permeabilized cells, it is possible to specifically introduce native cyclic nucleotides into the cytoplasmic space in order to test their functions. This model system bypasses cell surface receptors and the individual signal transduction pathways initiated by specific stimuli. It was therefore gratifying to find that low concentrations of cAMP (down to $3 \mu \mathrm{M}$ ) could inhibit $\mathrm{Ca}^{2+}$-induced degranulation. Maximal inhibition required $30-100 \mu \mathrm{M}$ cAMP and could reach $50 \%$, substantially more than seen with intact cells. The data in
Figures 2-4 show that the amount of inhibition obtained ranged from 25 to $60 \%$, which is most attributable to the variability normally seen in the responses of permeabilized neutrophils [41]. cGMP did not stimulate degranulation in this system; in fact, high concentrations of this cyclic nucleotide inhibited responsiveness. Dibutyryl cAMP was less effective than the native compound. This is likely to be due to the larger size of the derivatized agent which makes it comparable to the pore dimensions of electropermeabilized neutrophils $[10,41]$.

We also found that inhibition by cAMP required $\mathrm{Mg}^{2+}$ and was maximal when ATP was present. CAMP shifted the $\mathrm{Ca}^{2+}$ dose-response curve to the right and appeared to antagonize the potentiation by $\mathrm{Mg}$-ATP. The requirement for $\mathrm{Mg}^{2+}$ suggests two main possibilities for the mechanism of action of cAMP. The first possibility is that cAMP is somehow interacting with a recently described cell surface purine nucleotide receptor $[3,25]$. This receptor binds a number of nucleotides, in addition to ATP, in the presence of $\mathrm{Mg}^{2+}$ and can lead to enhancement of cellular function in intact [8] and permeabilized [41] cells. In permeabilized neutrophils, the purine nucleotide apparently activates protein kinase C, promoting degranulation [41]. In view of the broad nucleotide specificity of this receptor, it was possible that cAMP was binding to it as an inhibitor. However, increasing concentrations of ATP did not antagonize the effects of cAMP and so these two nucleotides were likely to be operating at different sites.

A second possible mechanism for the action of cAMP, which is consistent with the requirement for $\mathrm{Mg}^{2+}$, is the activation of a cAMP-dependent protein kinase (PKA). This enzyme has been isolated and characterized in neutrophils $[15,23,50]$ and a number of its acceptor proteins determined [14]. More specifically, PKA can phosphorylate a component of the NADPH oxidase [24] and regulate a component in the platelet-activating factor biosynthetic pathway [33]. However, in intact cells, endogenous protein phosphorylation is not apparently altered by dibutyryl cAMP [2], suggesting that cAMPdependent phosphorylation is only a fraction of the total kinase activity. Furthermore, we have shown that phosphorylation of endogenous proteins in neutrophil homogenates is primarily dependent upon $\mathrm{Mg}^{2+}$, without a requirement for other cofactors $[45,46]$. In view of this high background from competing kinases, it is not surprising that we were unable to detect any obvious acceptors for PKA. It is possible that this enzyme is phosphorylating some relatively rare component, such as another enzyme, which mediates inhibition by cAMP.

While it is clear that increments in cAMP do not play a positive effector role in signal transduction in neutrophils, it is also clear that they can play a modulatory role. The studies reported here demonstrate that low, physio- 
logically relevant concentrations of cAMP can inhibit secretion in a permeabilized model system in which normal receptor-ligand interactions are bypassed. The mechanism by which cAMP exerts its effects is unknown. Our own data indicate that PKC activation can overcome inhibition by cAMP (Fig. 5), suggesting that the nucleotide acts proximal to PKC. Other potential mechanisms were apparently excluded by Mueller and Sklar [29], who published evidence that inhibition of $\mathrm{O}_{2}^{-}$generation by beta-adrenergic agonists (and, presumably, cAMP) does not involve intracellular $\mathrm{Ca}^{2+}$, the activation of protein kinase $\mathrm{C}$, or the activation of G-proteins. Other reports indicate that inhibition by cAMP appears to require $\mathrm{Ca}^{2+}$ or calmodulin $[20,32]$ but does not involve perturbation of intracellular $\mathrm{Ca}^{2+}$ levels per se. Stimulated increases in endogenous cAMP also appear to require $\mathrm{Ca}^{2+}$ [51] and may be due to activation of adenylate cyclase by endogenously produced adenosine [16]. This close tie between cAMP and $\mathrm{Ca}^{2+}$ can be readily exploited by the permeabilized cell model and future experiments will attempt to more precisely localize the mode of action of this cyclic nucleotide.

\section{ACKNOWLEDGMENTS}

This work was supported by NIH grant DK32471 (J.E.S.).

\section{REFERENCES}

1. Worthington Enzyme Manual 100, 1972.

2. Andrews, P.C., and Babior, B.M. Phosphorylation of cytosolic proteins by resting and activated human neutrophils. Blood 64,883, 1984.

3. Axtell, R.A., Sandborg, R.R., Smolen, J.E., Ward, P.A., and Boxer, L.A. Exposure of human neutrophils to exogenous nucleotides causes elevation in intracellular calcium, transmembrane calcium fluxes, and an alteration of a cytosolic factor resulting in enhanced superoxide production in response to FMLP and arachidonic acid. Blood 75, 1324, 1990.

4. Baldys Waligorska A., Pur, A., Moriarty, C.M., and Dowd, F. The effect of calcium and cyclic AMP on amylase release in digitonin-permeabilized paratid gland cells. Biochim. Biophys. Acta 929,190, 1987.

5. Bers, D.M. A simple method for the accurate determination of free $(\mathrm{Ca})$ in Ca-EGTA solutions. Am. J. Physiol. 242,C404, 1982.

6. Boyum, A. Isolation of mononuclear cells and granulocytes from human blood. Isolation of mononuclear cells by centrifugation and of granulocytes by combining centrifugation and sedimentation at 1 G. Scand. J. Clin. Lab. Invest. 21,77, 1968.

7. Brittinger, G.R., Hirschborn, R., Douglas, S.D., and Weissmann, G. Studies on lysosomes. XI. Characterization of hydrolase-rich fraction from human lymphocytes. J. Cell Biol. 37,394, 1968.

8. Cockcroft, S., and Stutchfield, J. ATP stimulates secretion in human neutrophils and HL60 cells via a pertussis toxin-sensitive guanine nucleotide-binding protein coupled to phospholipase $\mathbf{C}$. FEBS Lett. 245,25, 1989.
9. De Togni, P., Cabrini, G., and Di Virgilio, F. Cyclic AMP inhibition of fMet-Leu-Phe-dependent metabolic responses in human neutrophils is not due to its effects on cytosolic $\mathrm{Ca}^{2+}$. Biochem. J., 224,269, 1984.

10. Grinstein, S., and Furuya, W. Receptor-mediated activation of electropermeabilized neutrophils. Evidence for $\mathrm{a} \mathrm{Ca}^{2+}$ and protein kinase $\mathrm{C}$-independent signaling pathway. J. Biol. Chem. $263,1779,1988$.

11. Herlin, T., and Borregaard, N. Early changes in cyclic AMP and calcium efflux during phagocytosis by neutrophils from normals and patients with chronic granulomatous disease. Immunology 48, 17, 1983.

12. Herlin, T., Petersen, C.S., and Esmann, V. The role of calcium and cyclic adenosine $3^{\prime}, 5^{\prime}$-monophosphate in the regulation of glycogen metabolism in phagocytozing human polymorphonuclear leukocytes. Biochim. Biophys. Acta 542,63, 1978.

13. Hopkins, N.K., Lin, A.H., and Gorman, R.R. Evidence for mediation of acetyl glyceryl ether phosphorylcholine stimulation of adenosine $3^{\prime}, 5^{\prime}$-(cyclic)monophosphate levels in human polymorphonuclear leukocytes by leukotriene B. Biochim. Biophys. Acta 763,276, 1983.

14. Huang, C.K., Hill, J.M., Jr., Bormann, B.J., Mackin, W.M., and Becker, E.L. Endogenous substrates for cyclic AMP-dependent and calcium-dependent protein phosphorylation in rabbit peritoneal neutrophils. Biochim. Biophys. Acta 760,126, 1983.

15. Huang, C.K., Mackin, W.M., Bormann, B.J., and Becker, E.L. Cyclic AMP receptor protein and cyclic AMP-dependent protein kinase activity in rabbit peritoneal neutrophils. J. Reticuloendothel. Soc. 34,413, 1983.

16. Iannone, M.A., Wolberg, G., and Zimmerman, T.P. Chemotactic peptide induces cAMP elevation in human neutrophils by amplification of the adenylate cyclase response to endogenously produced adenosine. J. Biol. Chem. 264,20177, 1989.

17. Ignarro, L.J., and George, W.J. Hormonal control of lysosomal enzyme release from human neutrophils: elevation of cyclic nucleotide levels by autonomic neurohormones. Proc. Natl. Acad. Sci. U.S.A. 71,2027, 1974.

18. Ignarro, L.J., and George, W.J. Mediation of immunologic discharge of lysosomal enzymes from human neutrophils by guanosine-3',5'-monophosphate. Requirement of calcium, and inhibition of adenosine-3', $5^{\prime}$-monophosphate. J. Exp. Med. 140,225, 1974.

19. Ignarro, L.J., Lint, T.F., and George, W.J. Hormonal control of lysosomal enzyme release from human neutrophils. Effects of autonomic agents on enzyme release, phagocytosis, and cyclic nucleotide levels. J. Exp.Med. 139,1395, 1974.

20. Ishitoya, J., and Takenawa, T. Potentiation of $\mathrm{PGE}_{1}$-induced increase in cyclic AMP by chemotactic peptide and $\mathrm{Ca}^{2+}$ ionophore through calmodulin-dependent processes. J. Immunol. 138,1201, 1987.

21. Jackowski, S., and Sha'afi, R.I. Response of adenosine cyclic $3^{\prime}, 5^{\prime}$-monophophate level in rabbit neutrophils to the chemotactic peptide formyl-methionyl-leucyl-phenylalanine. Mol. Pharmacol. 16,473, 1979.

22. Jones, P.M., Salmon, D.M.W., and Howell, S.L. Protein phosphorylation in electrically permeabilized islets of Langerhans: Effects of $\mathrm{Ca}^{2+}$, cyclic AMP, a phorbol ester and noradrenaline. Biochem. J. 254,397, 1988.

23. Juhl, H., and Esmann, V. Purification and properties of cAMP dependent and independent histone proteases from human leukocytes. Mol. Cell. Biochem. 26,3, 1979.

24. Kramer, I.M., van, der.Bend.R.L., Verhoeven, A.J., and Roos, D. The $47-\mathrm{kDa}$ protein involved in the $\mathrm{NADPH}: \mathrm{O}_{2}$ oxidoreductase activity of human neutrophils is phosphorylated by cyclic AMP-dependent protein kinase without induction of a respiratory burst. Biochim. Biophys. Acta 971,189, 1988. 
25. Kuhns, D.B., Wright, D.G., Nath, J., Kaplan, S.S., and Basford, R.E. ATP induces transient elevations of $\left[\mathrm{Ca}^{2+}\right] \mathrm{i}$ in human neutrophils and primes these cells for enhanced $\mathrm{O}_{2}^{-}$generation. Lab. Invest. 58,448, 1988.

26. Lad, P.M., Goldberg, B.J., Smiley, P.A., and Olson, C.V. Receptor-specific threshold effects of cyclic AMP are involved in the regulation of enzyme release and superoxide production from human neutrophils. Biochim. Biophys. Acta 846,286, 1985.

27. Laemmli, U.F. Cleavage of structural proteins during assembly of the head of bacteriophage T4. Nature 227,680, 1970.

28. Marx, R.S., McCall, C.E., and Bass, D.A. Chemotaxin-induced changes in cyclic adenosine monophosphate levels in human neutrophils. Infect. Immun. 29,284, 1980.

29. Mueller, H., and Sklar, L.A. Coupling of antagonistic signalling pathways in modulation of neutrophil function. J. Cell. Biochem. 40,287, 1989.

30. Naef, A., Damerau, B., and Keller, H.U. Relationship between the transient cAMP increase, exocytosis from specific and azurophil granules and chemotaxis in neutrophil granulocytes. Agents Actions 14,63, 1984.

31. Nasmith, P.E., Mills, G.B., and Grinstein, S. Guanine nucleotides induce tyrosine phosphorylation and activation of the respiratory burst in neutrophils. Biochem. J. 257,893, 1989.

32. Nielson, C.P. Beta adrenergic modulation of the polymorphonuclear leukocyte respiratory burst is dependent upon the mechanism of cell activation. J. Immunol. 139,2392, 1987.

33. Nieto, M.L., Velasco, S., and Sanchez Crespo, M. Modulation of acetyl-CoA:1-alkyl-2-lyso-sn-glycero-3-phosphocholine (lysoPAF) acetyltransferase in human polymorphonuclears. The role of cyclic AMP-dependent and phospholipid sensitive, calcium-dependent protein kinases. J. Biol. Chem. 262,4607, 1988.

34. Prentki, M., Wollheim, C.B., and Lew, P.D. Ca ${ }^{2+}$ homeostasis in permeabilized human neutrophils. Characterization of $\mathrm{Ca}^{2+}$. sequestering pools and the action of inositol 1,4,5-triphosphate. J. Biol. Chem. 259,13777, 1984.

35. Simchowitz, L., Atkinson, J.P., and Spilberg, I. Stimulusdependent deactivation of chemotactic factor-induced cyclic AMP response and superoxide generation by human neutrophils. J. Clin. Invest. 66,736, 1980.

36. Simchowitz, L., Fischbein, L.C., Spilberg, I., and Atkinson, J.P. Induction of a transient elevation in intracellular levels of adenosine- $3^{\prime}, 5^{\prime}$-monophosphate by chemotactic factors: an early event in human neutrophil activation. J. Immunol. 124,1482, 1980.

37. Simchowitz, L., Spilberg, I., and Atkinson, J.P. Evidence that the functional responses of human neutrophils occur independently of transient elevations in cyclic AMP levels. J. Cyclic Nucleotide Protein Phosphor. Res. 9,35, 1983.

38. Smith, G.P., and Peters, T.J. The release of granule components from human polymorphonuclear leukocytes in response to both phagocytic and chemical stimuli. Biochim. Biophys. Acta 719, 304, 1982.

39. Smolen, J.E. The fluorescence response of chlortetracyclineloaded human neutrophils is modulated by prostaglandin $E_{1}$, but not by cyclic nucleotides. FEBS Lett. 163,119, 1983.
40. Smolen, J.E., Korchak, H.M., and Weissmann, G. Increased levels of cyclic adenosine- $3^{\prime}, 5^{\prime}$-monophosphate in human polymorphonuclear leukocytes after surface stimulation. J. Clin. Invest. 65,1077, 1980.

41. Smolen, J.E., and Sandborg, R.R. $\mathrm{Ca}^{2+}$-induced secretion by electropermeabilized human neutrophils. The roles of $\mathrm{Ca}^{2+}$, nucleotides and protein kinase C. Biochim. Biophys. Acta $1052,133,1990$.

42. Smolen, J.E., and Stoehr, S.J. Micromolar concentrations of free calcium provoke secretion of lysozyme from human neutrophils permeabilized with saponin. J. Immunol. 134,1859, 1985.

43. Smolen, J.E., Stoehr, S.J., and Boxer, L.A. Human neutrophils permeabilized with digitonin respond with lysosomal enzyme release when exposed to micromolar levels of free calcium. Biochim. Biophys. Acta 886,1, 1986.

44. Smolen, J.E., and Weissmann, G. Stimuli which provoke secretion of azurophil granules induce increments in adenosine cyclic 3',5'-monophosphate. Biochim. Biophys. Acta 672,197, 1981.

45. Stoehr, S.J., and Smolen, J.E. Human neutrophils contain a protein kinase $\mathrm{C}$ which utilizes GTP as an alternate phosphate donor. Cofactor requirements, kinetics, and endogenous acceptor proteins. Blood 75,479, 1990.

46. Stoehr, S.J., Smolen, J.E., and Suchard, S.J. Lipocortins are major substrates for protein kinase $\mathrm{C}$ in extracts of human neutrophils. J. Immunol. 144,3936, 1990.

47. Takuma, T. Evidence against direct involvement of cyclic AMPdependent protein phosphorylation in the exocytosis of amylase. Biochem. J. 256,867, 1988.

48. Takuma, T., and Ichida, T. Amylase secretion from saponinpermeabilized parotid cells evoked by cyclic AMP. J. Biochem. (Tokyo) 103,95, 1988.

49. Tohmatsu, T., Nishida, A., Nagao, S., Nakashima, S., and Nozawa, Y. Inhibitory action of cyclic AMP on inositol 1,4,5triphosphate-induced $\mathrm{Ca}^{2+}$ release in saponin-permeabilized platelets. Biochim. Biophys. Acta 1013,190, 1989.

50. Tsung, P.K., Sakamoto, T., and Weissmann, G. Protein kinase and phosphatases from human polymorphonuclear leukocytes. Biochem. J. 145,437, 1975.

51. Verghese, M.W., Fox, K., McPhail, L.C., and Snyderman, R. Chemoattractant-elicited alterations of cAMP levels in human polymorphonuclear leukocytes require a $\mathrm{Ca}^{2+}$-dependent mechanism which is independent of transmembrane activation of adenylate cyclase. J. Biol. Chem. 260,6769, 1985.

52. Wada, Y. Cyclic AMP inhibits chemotactic-peptide-induced but not $\mathrm{Ca}^{2+}$-ionophore- or tetradecanoylphorbol-acetate-induced enzyme secretion in guinea pig neutrophils. Int. Arch. Allergy Appl. Immunol. 90,194, 1989.

53. Zurier, R.B., Hoffstein, S., and Weissmann, G. Cytochalasin B: effect on lysosomal enzyme release from human leukocytes. Proc. Natl. Acad. Sci. U.S.A. 70,844, 1973.

54. Zurier, R.B., Weissmann, G., Hoffstein, S., Kammerman, S., and Tai, H.H. Mechanisms of lysosomal enzyme release from human leukocytes. II. Effects of cAMP and cGMP, autonomic agonists, and agents which affect microtubule function. J. Clin. Invest. 53,297, 1974. 